\title{
Influence of Temperature on the Adsorption of Water Vapor by Collagen and Leather ${ }^{1}$
}

\begin{abstract}
By Joseph R. Kanagy
The adsorption of water vapor by collagen, commercial hide powder, and several leathers was determined at various relative humidities ranging from about 0 to 96 percent, at $28^{\circ}$, $50^{\circ}$, and $70^{\circ} \mathrm{C}$. Determinations were also made on chestnut and quebracho tannins at $28^{\circ} \mathrm{C}$ at various relative humidities. The results indicate that at 50 -percent relative humidity the variation of moisture content for 1 degree change in temperature is equivalent to that for 1 percent change in relative humidity. A specially purified collagen has higher affinity for water than does hide powder, showing that the previous chemical treatment influences adsorption. The results obtained from the experiments on the tannins and the hide powder show that tanning does not decrease water vapor adsorption at relative humidities below 70 percent.

From the results of the adsorption measurements, heats of adsorption were calculated by means of the Clausius-Clapeyron and Brunauer, Emmett, and Teller equations. The leathers show higher heats of adsorption for low moisture regains than does collagen, indicating that they contain some groups that are more highly active toward water than those in collagen. Free energy and entropy values for the adsorption at $50^{\circ} \mathrm{C}$ are given. The effect of high temperatures on moisture adsorption is studied by subjecting specimens to elevated temperatures and then determining the adsorption at $28^{\circ} \mathrm{C}$. Methods are given for estimating moisture content for conditions that have not been studied experimentally. The change of water adsorption with temperature can be expressed by a simple relation involving the log of the percentage of water adsorbed and the inverse of the absolute temperature.
\end{abstract}

\section{Introduction}

This is a continuation of the studies on the adsorption of moisture by collagen and different types of leathers. In a previous report [1] ${ }^{2}$ results were presented on the adsorption of moisture by hide powder (commercial grade of collagen) and various leathers at $100^{\circ} \mathrm{F}$. The Brunauer, Emmett, and Teller equation was applied to the data to obtain an estimate of the magnitude of the surfaces. The significance of these surface magnitudes with regard to manufacturing processes was shown.

\footnotetext{
1 This report is made as a part of the Leather Research Program sponsored by the Research and Development Branch, Military Planning Division of the Office of the Quartermaster General, Department of the Army. This program is under the Advisory Direction of the National Research Council. ${ }_{2}^{2}$ Figures in brackets indicate the literature references at the end of this paper.
}

The exact nature of the protein surfaces on which water is adsorbed is not known. Calculated surface areas can, therefore, be considered as having only comparative significance. It is most probable that adsorption occurs only at certain active places on the protein. These active points consist of the polar groups $-\mathrm{OH},-\mathrm{COOH}$, -- CO-NH, and $-\mathrm{NH}_{2}$. The degree of accur with which the surfaces are estimated would then depend upon the distribution of these groups. These groups differ among themselves in activity, and their affinity for water would probably also be modified by the group with which they are combined. Because there is a continuous gradation in affinity of the various groups for water, neither the adsorption isotherm nor its slope should have discontinuities. A theory similar to this has been expressed by Pauling [2]. 
Another approach to the study of protein surfaces and to the general nature of the adsorption process is through the calculation of the energy values involved. In a study of the energy values, an estimation of the range of activities of the polar groups may be obtained. Heats of adsorption for collagen have been determined by Bull [3] and by Dole and McLaren [4] from calculations using Bull's data. Frey and Moore [5] calculated the heats of adsorption of water by several amino acids including glycine from adsorptive data. These results are of considerable importance since they afford a comparison of a simple compound with that of a highly complicated protein system having a similar composition.

Several valuable contributions to the correlation and interpretation of adsorption data have been made by John C. Whitwell and his associates $[6,7,8]$ of the Textile Foundation at Princeton University. This work was done principally with the data obtained by Wiegerink [9] on textile materials. Among these contributions is a method for predicting moisture relation data for other conditions when data for only a few conditions are available.

A study of adsorption is of particular interest to the leather industry since an adsorption process is involved in tanning, dyeing, and lubrication with sulfonated oils. Another important process in leather making is drying. A determination of the energy values involved in the take-up of moisture and of the amounts of moisture in the leather under various conditions of relative humidity and temperature should be valuable in developing proper drying conditions. Moisture also has an effect on the physical properties and on the deterioration of leather.

In this study a determination of the amounts of water adsorbed by collagen and different types of leather at various relative humidities at $28^{\circ}$, $50^{\circ}$, and $70^{\circ} \mathrm{C}$ was made. Heats of adsorption, surface areas, and other physical constants were calculated from the data by the methods of thermodynamics and by some other methods that have been recommended by workers in other fields.

The effect of heating at elevated temperatures on the adsorption of water by collagen and different types of leather was also determined. In these experiments the samples were heated for a definite period of time at an elevated tempera- ture, and then the adsorption at $28^{\circ} \mathrm{C}$ was determined.

\section{Materials}

The collagen used in this work was a specially purified material. It was prepared from a freshly flayed hide by the method described by Cassel and Kanagy [10]. Data were also obtained with a less pure collagen known as Hide Powder. This material is prepared commercially and is used in the leather industry in tannin analyses. Some of the analytical data, together with other constants of these two types of collagen, are compared in table 1 .

TABLE 1. Analyses of collagens (dry basis)

\begin{tabular}{|c|c|c|c|c|}
\hline Material & $\begin{array}{c}\text { Total } \\
\text { nitrogen }\end{array}$ & $\begin{array}{l}\text { Amide } \\
\text { nitrogen } \\
\text { as per- } \\
\text { centage } \\
\text { of total } \\
\text { nitrogen }\end{array}$ & $\begin{array}{l}\text { Ash } \\
\text { con- } \\
\text { tent }\end{array}$ & $\begin{array}{l}\text { Iso- } \\
\text { elec- } \\
\text { tric } \\
\text { point }\end{array}$ \\
\hline $\begin{array}{l}\text { Hide powder (commercial col- } \\
\text { lagen preparation) }\end{array}$ & $\begin{array}{l}\text { Percent } \\
17.97 \\
17.40\end{array}$ & $\begin{array}{l}\text { 4. } 14 \\
2.46\end{array}$ & $\begin{array}{c}\text { Percent } \\
0.10 \\
.24\end{array}$ & $\begin{array}{l}p H \\
7.0 \\
5.1\end{array}$ \\
\hline
\end{tabular}

The leathers for which data are given in this report include sole, belting, chrome, and chromeretanned with vegetable. Sole and belting leathers are tanned entirely with vegetable tannins. Chrome leather is tanned with a basic chromium sulfate, and the chrome-retanned leather is produced by a combination tannage of chromium and vegetable. It is tanned first with a basic chromium sulfate. After this process is complete, it is retanned with vegetable tannins. The chemical analyses of the leathers used in this study are given in table 2 .

TABLE 2. Chemical analyses of leather (dry basis)

\begin{tabular}{|c|c|c|c|c|}
\hline Material & Sole & Chrome & $\begin{array}{c}\text { Re- } \\
\text { tanned } \\
\text { upper }\end{array}$ & $\begin{array}{c}\text { Vegeta- } \\
\text { ble- } \\
\text { tanned } \\
\text { belting }\end{array}$ \\
\hline Hide substance & Percent & Percent & Percent & Percent \\
\hline Ash & 6.2 & 7.1 & 2.6 & 0.4 \\
\hline Grease $\ldots \ldots$ & 14.2 & 7.1 & 39.1 & 10.9 \\
\hline Chromic oxide $\left(\mathrm{Cr}_{2} \mathrm{O}_{3}\right) \ldots \ldots$ & - n. & 4.8 & 2.0 & $\cdots$ \\
\hline Epsom salts $\left(\mathrm{MgSO}_{4} 7 \mathrm{H}_{2} \mathrm{O}\right) \ldots$ & 4.2 & & & 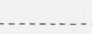 \\
\hline Water solubles.................... & 28.2 & & & \\
\hline Glucose & 6.9 & -.... & ...- & 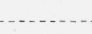 \\
\hline Moisture & 10.7 & 15.0 & 8.5 & 12.1 \\
\hline
\end{tabular}


The samples are from the same lots as were used in a previous investigation [15]. It has been shown that the variation of the amounts of moisture adsorbed by these samples when equilibrated at 50-percent relative humidity is within \pm 0.1 percent. The results given in this report were obtained on approximately 5 -g samples of the leathers after they had been degreased with chloroform.

\section{Method of Procedure}

The water adsorption data were obtained by exposing the samples in a cabinet in an atmosphere maintained at various constant relative humidities, using equipment similar to that described in a previous publication [1]. The relative humidity was obtained by the use of a saturated salt solution, and the samples were held at each constant condition for sufficient time to reach equilibrium. The cabinet was so constructed that the samples could be weighed without removal and while in equilibrium with the atmosphere.

The experiments were started with the samples held in an atmosphere maintained as closely to zero relative humidity as possible with phosphorus pentoxide. The relative humidity was then increased stepwise at intervals of about 10 percent. The samples were brought to equilibrium at each relative humidity. Eight to ten determinations of equilibrium adsorption were made over the range from zero to 100 -percent relative humidity at constant temperature. The temperature was maintained constant within \pm 0.5 deg and the relative humidity maintained within \pm 0.5 percent. The adsorption was assumed to be at equilibrium under any set of conditions when the change in the weight of the sample was not more than $0.001 \mathrm{~g}$ for a $24-\mathrm{hr}$ period.

The moisture adsorption is based on the "dry" weight of the material as determined by heating separate samples in an oven through which dry

TABLE 3. Water adsorbed by collagen, hide powder, and various leathers at different temperatures

\begin{tabular}{|c|c|c|c|c|c|c|c|c|c|c|c|c|c|c|c|c|c|c|}
\hline . & $\begin{array}{l}\text { Rela- } \\
\text { tive } \\
\text { hu- } \\
\text { mid- } \\
\text { ity }\end{array}$ & $\mathrm{g} / 100 \mathrm{~g}$ & $\begin{array}{l}\text { Rela- } \\
\text { tive } \\
\text { hu- } \\
\text { mid- } \\
\text { ity }\end{array}$ & $\mathrm{g} / 100 \mathrm{~g}$ & $\begin{array}{l}\text { Rela- } \\
\text { tive } \\
\text { hu- } \\
\text { mid- } \\
\text { ity }\end{array}$ & $\mathrm{g} / 100 \mathrm{~g}$ & $\begin{array}{l}\text { Rela- } \\
\text { tive } \\
\text { hu- } \\
\text { mid- } \\
\text { ity }\end{array}$ & $\mathrm{g} / 100 \mathrm{~g}$ & $\begin{array}{l}\text { Rela- } \\
\text { tive } \\
\text { hu- } \\
\text { mid- } \\
\text { ity }\end{array}$ & $\mathrm{g} / 100 \mathrm{~g}$ & $\begin{array}{l}\text { Rela- } \\
\text { tive } \\
\text { hu- } \\
\text { mid- } \\
\text { ity }\end{array}$ & $\mathrm{g} / 100 \mathrm{~g}$ & $\begin{array}{l}\text { Rela- } \\
\text { tive } \\
\text { hu- } \\
\text { mid- } \\
\text { ity }\end{array}$ & $\mathrm{g} / 100 \mathrm{~g}$ & $\begin{array}{c}\text { Rela- } \\
\text { tive } \\
\text { hu- } \\
\text { mid- } \\
\text { ity }\end{array}$ & $\mathrm{g} / 100 \mathrm{~g}$ & $\begin{array}{c}\text { Rela- } \\
\text { tive } \\
\text { hu- } \\
\text { mid- } \\
\text { ity }\end{array}$ & $g / 100 g$ \\
\hline & \multicolumn{18}{|c|}{$28^{\circ} \mathrm{C}$} \\
\hline Collagen .. & 14. 2 & 6.57 & 24.0 & 9. 79 & 34.0 & 12. 73 & 44. 7 & 16.00 & 53.6 & 20.59 & 62.4 & 23.61 & 73.4 & 29.18 & 83.6 & 35.80 & 96.0 & 53.35 \\
\hline Hide powder & 14. 2 & 5. 83 & 24.0 & 8.31 & 34.0 & 10.34 & 44.7 & 12.62 & 53.6 & 15.89 & 62.4 & 18.17 & 73.4 & 22.89 & 83.8 & 29.97 & 96.0 & 51.22 \\
\hline Vegetable-tanned belting & & & & & & & & & & & & & & & & & & \\
\hline leather & 14. 2 & 6.28 & 24.0 & 8. 42 & 34.0 & 10.20 & 44.7 & 12.14 & 53.6 & 14. 72 & 62.4 & 16.21 & 73.4 & 19. 27 & 83.6 & 23.17 & 96.0 & 32.62 \\
\hline Chrome-retanned upper & & & & & & & & & & & & & & & & & & \\
\hline leather & 14. 2 & 6. 30 & 24.0 & 8.48 & 34.0 & 10.22 & 44. 7 & 12.27 & 53.6 & 15.00 & 62.4 & 16.45 & 73.4 & 19. 47 & 83.6 & 23. 79 & 96.0 & 33.82 \\
\hline Sole leather & 14. 2 & 6.44 & 24.0 & 8.53 & 34.0 & 10.11 & 44. 7 & 11.67 & 53.6 & 13.82 & 62.4 & 15.40 & 73.4 & 20.97 & 83.6 & 29.56 & 96.0 & 54.59 \\
\hline \multirow[t]{2}{*}{ Chrome leather } & 14. 2 & 7. 43 & 24.0 & 10.03 & 34.0 & 12.13 & 44. 7 & 14.19 & 53.6 & 17.09 & 62.4 & 19.06 & 73.4 & 23.84 & 83.6 & 31.57 & 96.0 & 54.88 \\
\hline & \multicolumn{18}{|c|}{$50^{\circ} \mathrm{C}$} \\
\hline Collagen.. & 12.0 & 4. 69 & 21.0 & 7.33 & 28.5 & 9.44 & 44.5 & 12.50 & 49.0 & 14.67 & 58.0 & 17.58 & 71.0 & 23.53 & 82.0 & 28.90 & 93.5 & 40.66 \\
\hline Hide powder & 12.0 & 4.07 & 21.0 & 6. 20 & 28.5 & 7.77 & 44.5 & 10.20 & 49.0 & 11.82 & 58.0 & 14.04 & 71.0 & 19.18 & 82.0 & 24.79 & 93.5 & 40.12 \\
\hline Vegetable-tanned belting & & & & & & & & & & & & & & & & & & \\
\hline leather & 12.0 & 4.82 & 21.0 & 6.58 & 28.5 & 8.04 & 44.5 & 9.86 & 49.0 & 11.07 & 58.0 & 12.81 & 71.0 & 16. 20 & 82.0 & 19.07 & 93.5 & 24.73 \\
\hline Chrome-retanned upper & & & & & & & & & & & & & & & & & & \\
\hline leather....... & 12.0 & 5. 00 & 21.0 & 6. 93 & 28.5 & 8.43 & 44.5 & 10.40 & 49.0 & 11.69 & 58.0 & 13.50 & 71.0 & 17.35 & 82.0 & 20.37 & 93.5 & 27.52 \\
\hline Sole leather & 12.0 & 4. 53 & 21.0 & 6. 24 & 28.5 & 7. 63 & 44.5 & 9.32 & 49.0 & 10.62 & 58.0 & 12. 28 & 71.0 & 16.13 & 82.0 & 23. 72 & 93.5 & 45. 77 \\
\hline \multirow[t]{2}{*}{ Chrome leather } & 12.0 & 5.67 & 21.0 & 7.84 & 28.5 & 9.47 & 44.5 & 11.87 & 49.0 & 13.36 & 58.0 & 15.77 & 71.0 & 21.35 & $\varepsilon 2.0$ & 26.75 & 93.5 & 44. 72 \\
\hline & \multicolumn{18}{|c|}{$70^{\circ} \mathrm{C}$} \\
\hline Collagen & 13.0 & 4.01 & 24.5 & 6.38 & 30.0 & 6. 91 & 36.0 & 8.75 & 47.5 & 11. 26 & 67.0 & 17. 10 & 75.0 & 20.11 & 81.0 & 24.59 & & - \\
\hline Hide powder & 13.0 & 3.59 & 24.5 & 5. 63 & 30.0 & 6.12 & 36.0 & 7. 66 & 47.5 & 9.92 & 67.0 & 15.40 & 75.0 & 18.88 & 81.0 & 24.41 & & - \\
\hline $\begin{array}{l}\text { Vegetable-tanned belting } \\
\text { leather }\end{array}$ & 13.0 & 3.41 & 24.5 & 5.14 & 30.0 & 5. 54 & 36.0 & 6.78 & 47.5 & 8.56 & 67.0 & 12. 18 & 75.0 & 13.30 & 81.0 & 15.44. & & \\
\hline Chrome-retanned upper & & & & & & & & & & & & & & & & & & \\
\hline leather & 13.0 & 3.81 & 24.5 & 5.65 & 30.0 & 6.13 & 36.0 & 7.41 & 47.5 & 9.48 & 67.0 & 12. 75 & 75.0 & 14.99 & 81.0 & 17. 77 . & & \\
\hline Sole leather & 13.0 & 3.49 & 24.5 & 5.11 & 30.0 & 5. 54 & 36. 0 & 6.84 & 47.5 & 8.45 & 67.0 & 12.86 & 75.0 & 13.70 & 81.0 & 19. 79 & & -...... \\
\hline Chrome leather & 13.0 & 4.48 & 24.5 & 6.50 & 30.0 & 7.10 & 36.0 & 8. 77 & 47.5 & 11. 38 & 67.0 & 17.04 & 75.0 & 19.79 & 81.0 & 24.86 & $\ldots$ & -... \\
\hline
\end{tabular}


air was passed at $100^{\circ} \mathrm{C}$ for $18 \mathrm{hr}$. Separate samplès were used for this determination because subjection to high temperatures is believed to influence subsequent adsorption of moisture. Since the percentages of water adsorbed are based on the dry weights of the samples, the adsorption is expressed directly in grams per $100 \mathrm{~g}$ of the dry material. The results of the water adsorption measurements at different temperatures for collagen, commercial Hide Powder, vegetable-tanned belting leather, chrome-retanned upper leather, sole leather, and chrome-tanned leather are given in table 3.

\section{Adsorption Isotherms}

In figure 1 are compared the adsorption isotherms of purified collagen, commercial Hide Powder, and vegetable-tanned belting leather at $28^{\circ} \mathrm{C}$. These results show that the collagen has a greater affinity for moisture than does the Hide Powder.

As shown in table 1, the chemical analyses of the two collagens differ considerably, and the difference in the amide nitrogen content possibly accounts for a part of the difference in moisture adsorption. Moisture adsorption apparently is highly dependent upon the previous chemical treatments of the samples. The vegetable-tanned

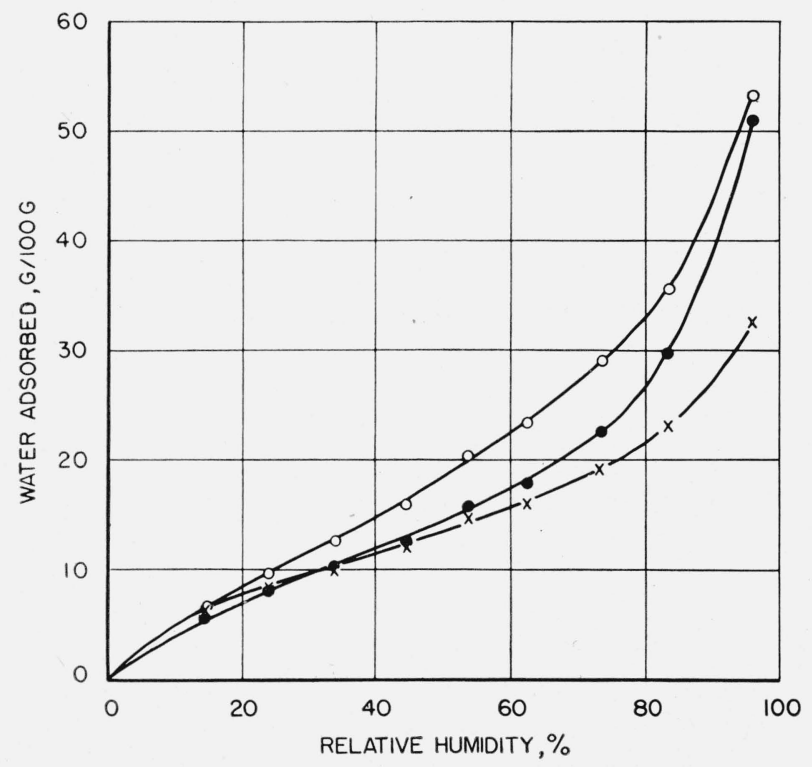

Figure 1. Comparison of the adsorption of water vapor by collagen, $\bigcirc$, hide powder, $\bigcirc$, and vegetable-tanned belting leather $X$, at $28^{\circ} \mathrm{C}$.

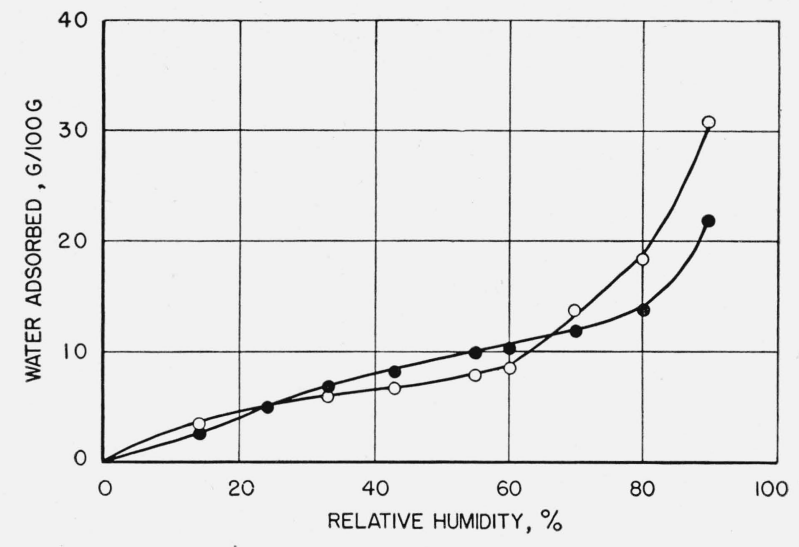

Figure 2. Comparison of the adsorption of water vapor by chestnut tannin, $\bigcirc$, and quebracho tannin, at $28^{\circ} \mathrm{C}$.

belting leather shows equal affinity for water with collagen at low relative humidities; however, at the higher relative humidities, collagen shows much greater adsorption.

The moisture adsorption isotherms for chrome, vegetable-tanned sole, and chrome-retanned leather are similar to those shown in figure 1 . The amounts of moisture adsorbed by sole leather and chrome-retanned leather are almost identical at low relative humidities. These amounts are about equivalent to those for vegetable-tanned belting leather. Chrome leather shows more adsorption than the other leathers, probably because it contains a greater percentage of hide substance. At 96-percent relative humidity, sole leather adsorbs approximately the same amount of water as collagen. Sole leather shows an abrupt increase in adsorptive properties at a relative humidity of about 70 percent because of the salts that it contains [1].

Adsorption isotherms for quebracho and chestnut tannin extracts are given in figure 2 .

These results indicate that these two tannins differ somewhat in their reaction with water. Chestnut tannin shows more adsorption at relative humidities under 20 percent. Quebracho tannin shows more adsorption than chestnut between 25- and 60-percent relative humidity. Above 60percent chestnut tannin again shows greater adsorption. Both tannins adsorb less than collagen or leather. The isotherms, however, are similar in shape to those of leather or collagen.

In order to determine if the differences in the amounts of moisture adsorbed by leather and by hide substance were caused by the dilution effect 
of the tannin, a calculation was made, based on the percentages of hide substance and of tannin in belting leather. The amount of adsorption attributable to the tannin was calculated on the basis of the mean adsorption for quebracho and chestnut tannin (fig. 2), and that for the hide substance was based on the results given for hide substance in table 3 . In figure 3 , these calculated values are compared with the results obtained for belting leather.

Up to about 75-percent relative humidity, the observed adsorption exceeds the calculated values, whereas at higher relative humidities the calculated values exceed the observed values.

It may be concluded from these results that tanning with vegetable tannins does not decrease the attraction of the material for water at low relative humidities. It does, however, decrease the adsorption at high relative humidities, probably because the vegetable tannins prevent swelling. These results indicate that one of the results of tanning is the prevention of swelling.

The effect of temperature on the adsorption of water by collagen and vegetable-tanned belting leather is shown in figures 4 and 5, respectively. As the temperature is increased, less moisture is adsorbed at any given relative humidity by both materials under the conditions studied. Isotherms at each temperature are nearly parallel and have approximately the same shape. Similar trends were shown by all the other materials on which determinations were made.

At 50-cent relative humidity, the change in moisture content per degree variation in tempera-

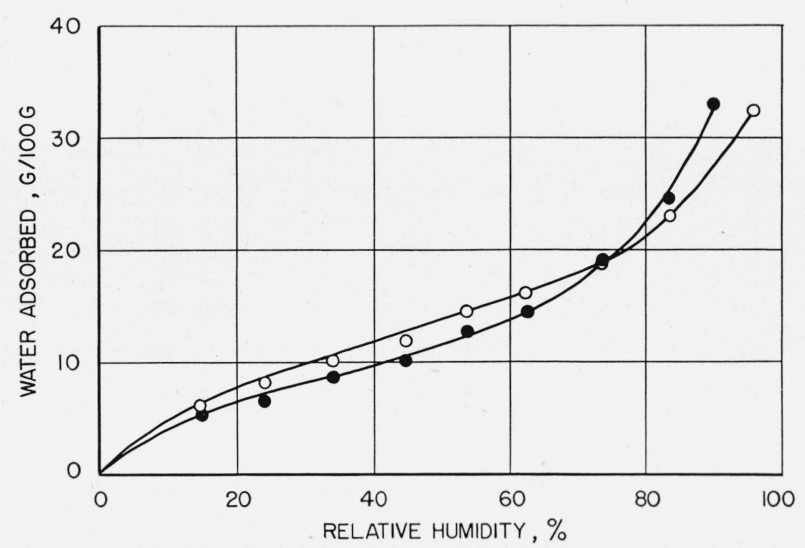

Figure 3. Comparison of the actual adsorption of water vapor by vegetable-tanned belting leather, $\bigcirc$, with that calculated for this leather from its content of hide substance and tannin,

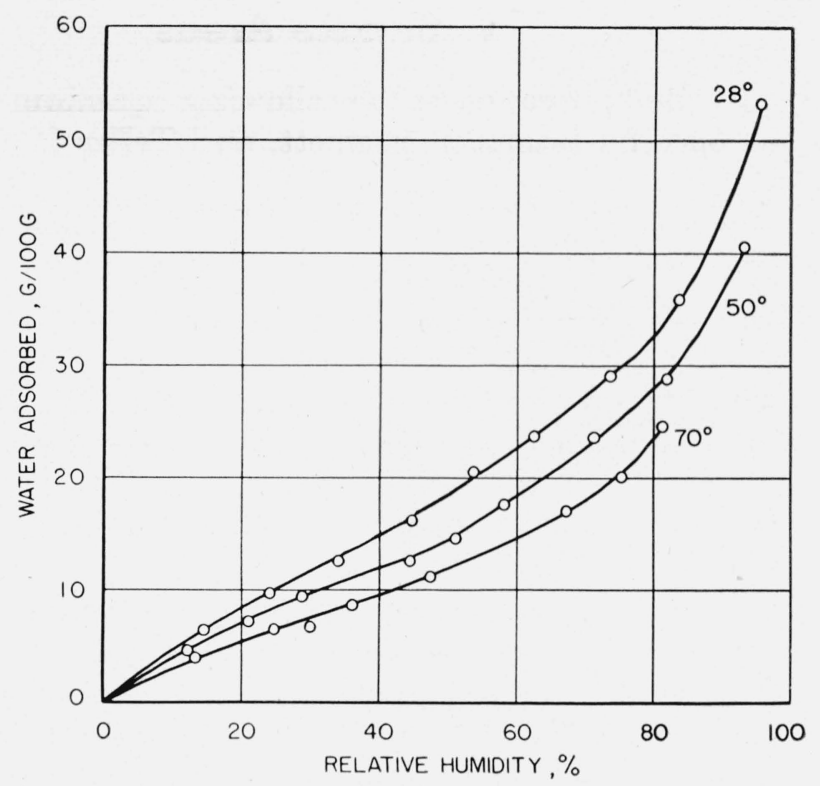

Figure 4. Influence of temperature on the adsorption of water-vapor by collagen.

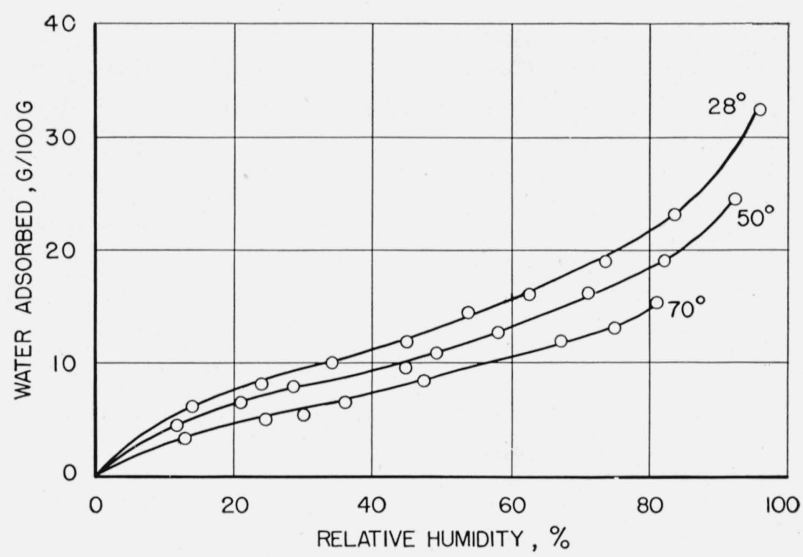

FiguRE 5. Influence of temperature on the adsorption of water vapor by vegetable-tanned belting leather.

ture is about equal to the change for a 1-percent variation in relative humidity. These results show the importance of temperature in the conditioning of leather to a uniform moisture content. Not only must the relative humidity be held constant, but it is equally important to hold the temperature constant. On the basis of these results, it may be observed that in a room maintained at the optimum constant temperature, which is about a 1-deg variation, the moisture content will vary about 0.15 percent. This emphasizes the futility of attempting to determine or maintain moisture values to a greater precision than 0.1 to 0.2 percent. 


\section{Surface Âreas}

By application of the following equation developed by Brunauer, Emmett, and Teller [16]

$$
\frac{P}{V\left(P_{0}-P\right)}=\frac{C-1}{V_{m} C} \frac{P}{P_{0}}+\frac{1}{V_{m} C}
$$

it is possible to make a calculation of the surface areas of the sample that is involved in the adsorption. It is realized that this equation was derived for adsorption on a simple surface under ideal conditions, but it is of interest to find out to what extent it might be applied to a more complicated surface, such as that of a protein.

The calculations are made by plotting $P / V\left(P_{0}-P\right)$ against $P / P_{0}$. The straight line obtained from this plot will have a slope equal to $(C-1) / V_{m} C$ and an intercept equal to $1 / V_{m} C$. From these two quantities, values for $V_{m}$ and $C$ may be calculated. $V_{m}$ is the volume of water vapor at $0^{\circ} \mathrm{C}$ and 760 $\mathrm{mm}$ required to form a unimolecular layer and, $C$ is a constant that is related to the heat of adsorption. By multiplying $V_{m}$ by 2.705 , a value for the surface area of the sample is obtained when water is used as the adsorbate. The derivation of this constant is given in a previous publication.

The constant used is based on the size of the water molecule at $0^{\circ} \mathrm{C}$, whereas the measurements are made at higher temperatures. This does not introduce any serious error since the size of the water molecule, as determined from density values, does not change more than about 3 percent over the range $0^{\circ}$ to $70^{\circ} \mathrm{C}$.

Values for $V_{m}, C$, and the calculated surface areas are given in table 4 . The results indicate less available surface as the temperature is increased. Between $50^{\circ}$ and $70^{\circ} \mathrm{C}$ the greatest decrease in available surface occurs. The decrease in the available surface with increase in temperature is not caused by any drastic irreversible change in the surfaces of the sample. This is demonstrated by the fact that if adsorption measurements are repeated at $28^{\circ} \mathrm{C}$ on the samples on which determinations have been made at $70^{\circ} \mathrm{C}$, the amounts adsorbed approach those determined initially at $28^{\circ} \mathrm{C}$. Nor is it caused by an increase in the size of the water molecule with increase in temperature as estimated from the decrease in density of water with increase in temperature.

TABLE 4. Surface areas and values of $C$ for collagens, leathers, and tanning materials at different temperatures as determined by the application of the BET equations

\begin{tabular}{|c|c|c|c|c|c|c|c|c|c|}
\hline \multirow{3}{*}{ Sample } & \multicolumn{9}{|c|}{ Temperature } \\
\hline & \multicolumn{3}{|c|}{$28^{\circ} \mathrm{C}$} & \multicolumn{3}{|c|}{$50^{\circ} \mathrm{C}$} & \multicolumn{3}{|c|}{$70^{\circ} \mathrm{C}$} \\
\hline & $C$ & $V_{m}$ & $\begin{array}{l}\text { Surface } \\
\text { area }\end{array}$ & $C$ & $\mathrm{~T}_{m}$ & $\begin{array}{l}\text { Surface } \\
\text { area }\end{array}$ & $C$ & $T_{m}$ & $\begin{array}{l}\text { Surface } \\
\text { area }\end{array}$ \\
\hline & & $m l / g$ & $m^{2} / g$ & & $m l / g$ & $m^{2} / g$ & & $\mathrm{ml} / \mathrm{g}$ & $m^{2} / g$ \\
\hline Collagen - - & 6.3 & 136.8 & 370 & 5.2 & 124. 2 & 340 & 9.3 & 76.3 & 210 \\
\hline Hide powder (commercial collagen) ..... & 9.8 & 103.3 & 280 & 7.1 & 92.4 & 250 & 12. 7 & 64.3 & 170 \\
\hline Belting leather & 14.3 & 96.3 & 260 & 10.8 & 87.4 & 240 & 12.2 & 58.3 & 160 \\
\hline Chrome leather & 13.9 & 115.4 & 310 & 11.1 & 103. 0 & 280 & 13.6 & 73.5 & 200 \\
\hline 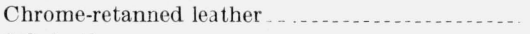 & 15. 7 & 94.1 & 260 & 10.9 & 91.8 & 250 & 9.3 & 68.2 & 180 \\
\hline Sole leather & 17.1 & 94.0 & 250 & 10.0 & 85.0 & 230 & 13.6 & 58.0 & 160 \\
\hline 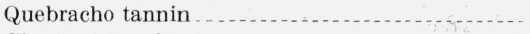 & 1.8 & 122.2 & 330 & -.... & - & -..... & ...... & - . - & - . - \\
\hline Chestnut tannin $\ldots \ldots \ldots \ldots$ & 11.1 & 60.0 & 160 & ..... & ...... & ....... & ...... & -...- & (n) \\
\hline
\end{tabular}

The decrease in the calculated available surface as the temperature is increased may be explained by (1) inadequacy of the BET equation when applied to a complicated protein surface, (2) a reversible change in the surface, or (3) a combination of both factors. Since the calculated surface areas depend upon the amount of gas adsorbed, it is obvious that they decrease with an increase in temperature. The BET equation is therefore not rigorously applicable under these conditions, and any surface area determinations are strictly relative, and comparison should be limited to surface areas calculated for a constant temperature.

\section{Heats of Adscrption}

In order to obtain more fundamental information on the nature of the adsorption of water by collagen and leather, studies of the heats of adsorption were made. 


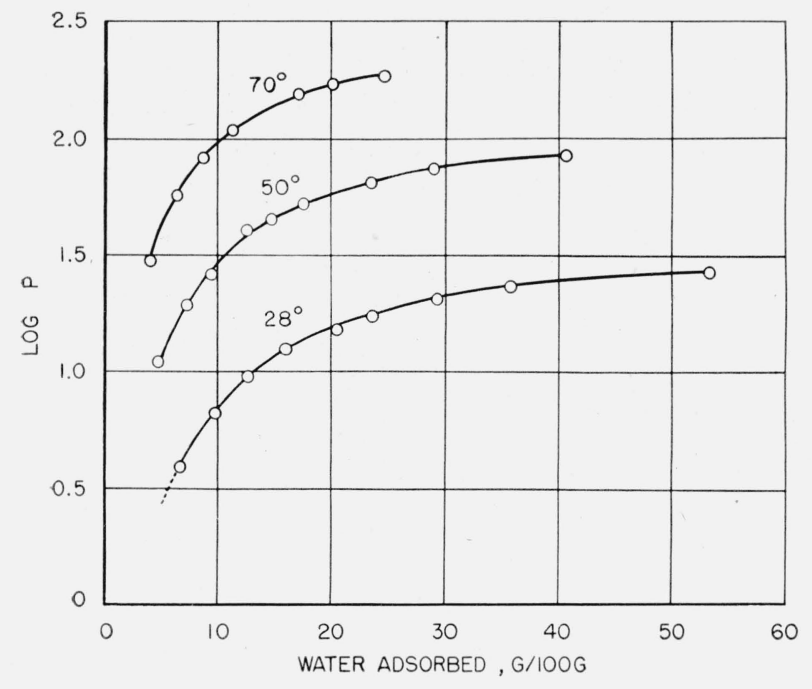

Figure 6. Variation of the percentage of water adsorbed by collagen with the logarithm of the vapor pressure.

A number of methods for studying heats of adsorption for the system

water vapor $\rightleftarrows$ water vapor adsorbed,

may be applied.

The differential heat of adsorption may be calculated by means of the Clausius-Clapeyron equation

$$
\Delta H=R 2.303 \frac{\log P_{2}-\log P_{1}}{\frac{1}{T_{1}}-\frac{1}{T_{2}}},
$$

where $\Delta H$ is the differential heat of adsorption, $R$ is the gas constant, and $P_{2}$ and $P_{1}$ are the vapor pressures of water in equilibrium with the samples at the absolute temperatures $T_{2}$ and $T_{1}$, respectively. $P_{2}$ and $P_{1}$ are the vapor pressures of water in equilibirum with the same amount of adsorbed water at the temperatures $T_{2}$ and $T_{1}$. In making the calculations, the log of the vapor pressure is plotted against the amount of water adsorbed. Such a plot for collagen is shown in figure 6 .

The differences between the log of the vapor pressures at any two temperatures for constant water adsorption are obtained from the graph and substituted into the equation given above. The results obtained are the change in the heat content involved in the process

$$
\mathrm{H}_{2} \mathrm{O}(g) \rightleftarrows \mathrm{H}_{2} \mathrm{O} \text { (adsorbed). }
$$

The results for collagen, hide powder, and four different samples of leather are given in table 5 .
No data for heats of adsorption for less than 5 percent of water are given since the adsorption of lower amounts of moisture was not studied. The curve showing the change of moisture adsorbed with the $\log$ of the vapor pressure at $28^{\circ} \mathrm{C}$ was extrapolated to the 5-percent point.

Heats of adsorption may also be calculated from a relation derived by Brunauer, Emmett, and Teller [16]

$$
E_{1}-E_{L}=R T \ln C,
$$

where $C$ is the constant calculated from eq 1 . Values for $C$ for each experimental material are given in table $4 . E_{1}$ is the heat of adsorption in the first layer, and $E_{L}$ is the heat of condensation. By the addition of the heat of condensation to the value obtained for $E_{1}-E_{L}$, the heat of adsorption for the first layer is obtained. This should be an approximate value of the heat of adsorption at low vapor pressures. The results of these calculations are given in table 5 .

It may be observed that these values are nearly constant for all three temperatures, with some of the samples showing a slight decrease as the temperature is increased. These results consist of average values for the heats of adsorption over the partial pressure range 0 to 0.3 or for the adsorption of up to about 10 percent of water. These results indicate that the values obtained with the BET equations are lower than those obtained from the equation of Clausius-Clapeyron. A similar trend was noted by Dole and McLaren [4]. The differential heats of adsorption (heats of adsorption calculated from the ClausiusClapeyron equation) are highest for the lower amounts of moisture adsorbed but approach the heat of condensation as the amounts adsorbed increase. On the average, the differential heats of adsorption are lower in the temperature range $50^{\circ}$ to $70^{\circ} \mathrm{C}$ than in the range $28^{\circ}$ to $50^{\circ} \mathrm{C}$.

In figure 7 the differential heats of adsorption for collagen, chrome leather, and vegetabletanned belting leather are plotted against $V / V_{m}$. The results indicate that the heats of adsorption drop abruptly at a $V / V_{m}$ value of about 1 and become constant at about 3 . For less than one monomolecular layer the increase in the heat of adsorption is even more rapid with decreasing amounts of water adsorbed for vegetable and chrome-tanned leather. Collagen shows the lowest heat of adsorption for low percentages of water 
TABLE 5. Heats of adsorption (calories/mole)

\begin{tabular}{|c|c|c|c|c|c|c|}
\hline Methods & Collagen & $\begin{array}{l}\text { Hide } \\
\text { powder }\end{array}$ & $\begin{array}{l}\text { Chrome- } \\
\text { tanned } \\
\text { leather }\end{array}$ & $\begin{array}{l}\text { Belting } \\
\text { leather }\end{array}$ & $\begin{array}{l}\text { Chrome- } \\
\text { retanned } \\
\text { leather }\end{array}$ & $\begin{array}{c}\text { Sole } \\
\text { leather }\end{array}$ \\
\hline \multirow{2}{*}{\multicolumn{7}{|c|}{$\begin{array}{l}\text { Calculated from Clausius-Clapeyron } \\
\text { equation: } \\
\text { 5-Percent adsorption: }\end{array}$}} \\
\hline & & & & & & \\
\hline $28^{\circ}$ to $50^{\circ} \mathrm{C}$ & 14,000 & 13,300 & 15,400 & 16,700 & 16,400 & 15,200 \\
\hline $50^{\circ}$ to $70^{\circ} \mathrm{C}$ & 13,100 & 13,500 & 15,100 & 16,600 & 16,200 & 15,200 \\
\hline Average $28^{\circ}$ to $70^{\circ} \mathrm{C}$ & 13,600 & 13,400 & 15,300 & 16,700 & 16,300 & 15,200 \\
\hline \multicolumn{7}{|l|}{ 6-Percent adsorption: } \\
\hline $28^{\circ}$ to $50^{\circ} \mathrm{C}$ & 13,600 & 13,500 & 14,700 & 15,100 & 13,700 & 15,000 \\
\hline $50^{\circ}$ to $70^{\circ} \mathrm{C}$ & 13,300 & 12,800 & 15,100 & 16,200 & 16,100 & 15,100 \\
\hline Average $28^{\circ}$ to $70^{\circ} \mathrm{C}$ & 13,500 & 13,200 & 14,900 & 15,700 & 14,900 & 15,100 \\
\hline \multicolumn{7}{|l|}{ 8-Percent adsorption: } \\
\hline $28^{\circ}$ to $50^{\circ} \mathrm{C}$ & 13,500 & 13,600 & 13,600 & 13,500 & 12,900 & 13,900 \\
\hline $50^{\circ}$ to $70^{\circ} \mathrm{C}$ & 13,100 & 11,700 & 13,200 & 14,000 & 14,000 & 13,100 \\
\hline Average $28^{\circ}$ to $70^{\circ} \mathrm{C}$ & 13,300 & 12,700 & 13,400 & 13,800 & 13,500 & 13,500 \\
\hline \multicolumn{7}{|l|}{ 10-Percent adsorption: } \\
\hline $28^{\circ}$ to $50^{\circ} \mathrm{C}$ & 13,600 & 13,600 & 13,400 & 13,000 & 12,600 & 13,800 \\
\hline $50^{\circ}$ to $70^{\circ} \mathrm{C}$ & 12,500 & 10,700 & 12,400 & 12,600 & 12,800 & 11,700 \\
\hline Average $28^{\circ}$ to $70^{\circ} \mathrm{C}$ & 13,100 & 12,200 & 12,900 & 12,800 & 12,700 & 12,800 \\
\hline \multicolumn{7}{|l|}{ 15-Percent adsorption: } \\
\hline $28^{\circ}$ to $50^{\circ} \mathrm{C}$ & 12,400 & 12,000 & 12,100 & 12,400 & 11,800 & 12,000 \\
\hline $50^{\circ}$ to $70^{\circ} \mathrm{C}$ & 11,900 & 10,700 & 10,900 & 11,500 & 11,100 & 10,600 \\
\hline Average $28^{\circ}$ to $70^{\circ} \mathrm{C}$ & 12,200 & 11,400 & 11,500 & 12,000 & 11,500 & 11,300 \\
\hline \multicolumn{7}{|l|}{ 20-Percent adsorption: } \\
\hline $28^{\circ}$ to $50^{\circ} \mathrm{C}$ & 12,000 & 11,700 & 11,100 & 11,800 & 11,300 & 11,700 \\
\hline $50^{\circ}$ to $70^{\circ} \mathrm{C}$ & 11,300 & 10,100 & 11,000 & -...... & ...... & 10,200 \\
\hline Average $28^{\circ}$ to $70^{\circ} \mathrm{C}$ & 11,700 & 10,900 & 11,100 & -..... & -.... & 11,000 \\
\hline \multicolumn{7}{|l|}{ 25-Percent adsorption: } \\
\hline $28^{\circ}$ to $50^{\circ} \mathrm{C}$ & 11,500 & 11,500 & 10,900 & 11,300 & 11,300 & 11,400 \\
\hline $50^{\circ}$ to $70^{\circ} \mathrm{C}$ & 10,800 & 9,700 & 10,400 & -..... & $\ldots$ & $-\cdots$ \\
\hline Average $28^{\circ}$ to $70^{\circ} \mathrm{C}$ & 11,200 & 10,600 & 10,700 & -.....- & -..... & -....- \\
\hline \multicolumn{7}{|l|}{ 40-Percent adsorption: } \\
\hline $28^{\circ}$ to $50^{\circ} \mathrm{C}$ & 11,200 & 10,900 & 10,800 & n.... & $-\cdots$ & 10,900 \\
\hline \multicolumn{7}{|l|}{ From B E T equation: } \\
\hline $28^{\circ} \mathrm{C}$ & 11,600 & 11,800 & 12,000 & 12,100 & 12,100 & 12,200 \\
\hline $50^{\circ} \mathrm{C}$ & 11,300 & 11,500 & 11,800 & 11,800 & 11,800 & 11,700 \\
\hline $70^{\circ} \mathrm{C} \ldots \ldots \ldots$ & 11,600 & 11,800 & 11,800 & 11,800 & 11,600 & 11,800 \\
\hline A verage $28^{\circ}$ to $70^{\circ} \mathrm{C}$ & 11,500 & 11,700 & 11,900 & 11,900 & 11,800 & 11,900 \\
\hline
\end{tabular}

vapor adsorbed; whereas that for vegetabletanned leather is highest, and that for chrometanned leather is intermediate.

The differences between the heats of adsorption of water by collagen, chrome, and vegetabletanned belting leather for less than unimolecular take-up may be explained on the basis of different electronegativities of the carboxyl ions and carboxyl groups. Results of electrophoretic measurements [13] on these three materials indicate most strongly negative groups for vegetabletanned leather, intermediate for chrome, and least strongly negative groups for collagen, which is precisely the order of decreasing heats of adsorption for water for a content of less than a monomolecular layer. The strongest negative charges are assumed to arise from the ionization of the carboxyl group, $\mathrm{RCOOH} \rightarrow \mathrm{RCOO}^{-}+\mathrm{H}^{+}$. Water combines strongly with the carboxyl ion by hydrogen bonding as follows:<smiles>[R]O[Hg]O[R]</smiles>

Unionized carboxyl groups also combine strongly by hydrogen bonding to water.

The high heats of adsorption for low pickups of water may be explained by the assumption that each molecule forms two hydrogen bonds. Since the energy involved for each bond may be as much as 6 to $8 \mathrm{~K}$ calories, the formation of two bonds would bring the energy values into the range actually observed. The fact that the high values are obtained for only small amounts of adsorption indicates that there are very few protein groups that combine with water in this way. It is doubtful if either a single free amino or peptide group 


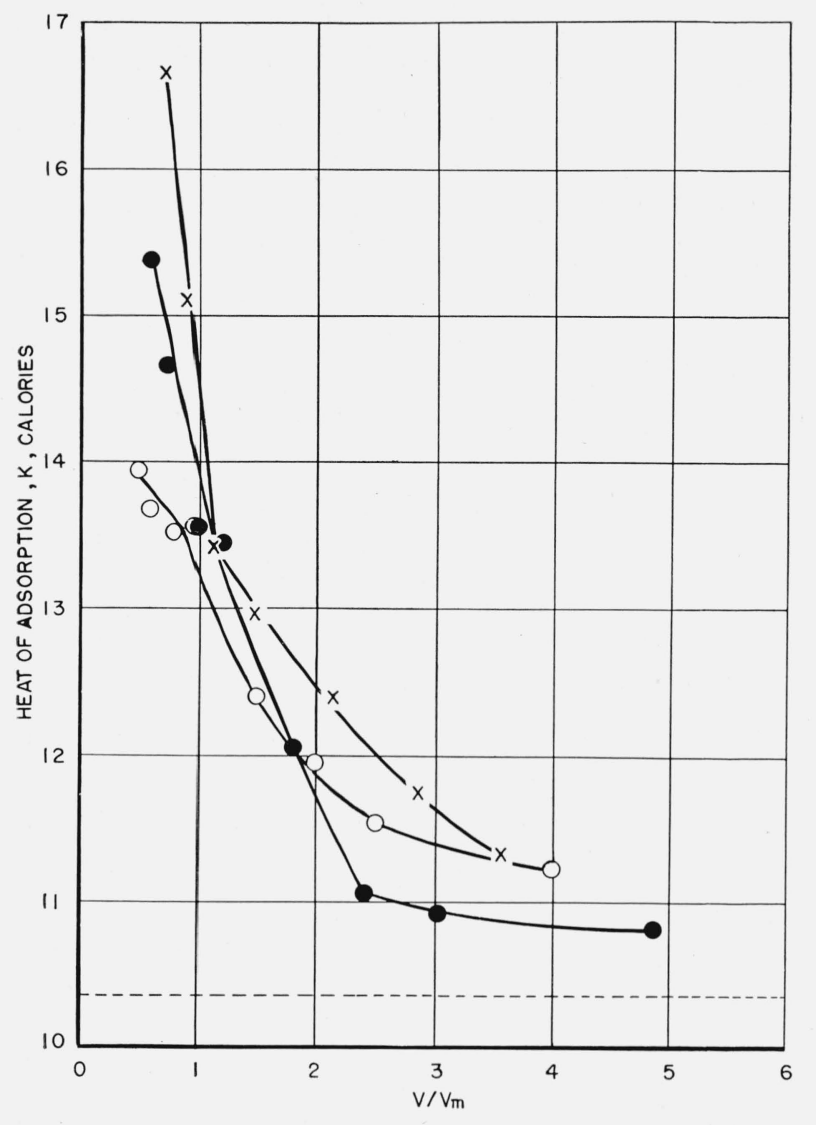

Figure 7. Variation of the differential heats of adsorption for the range $28^{\circ}$ to $50^{\circ} \mathrm{C}$ for collagen, $\bigcirc$, vegetable-tanned belting leather, $X$, and chrome leather, $\mathbf{O}$, with $V / V_{\boldsymbol{m}}$.

Broken line, - - , indicates heat of condensation of water at $50^{\circ} \mathrm{C}$.

is involved in this type of combination. However, there is a possibility of some cross linking between two such groups.

The high heats of adsorption for the vegetabletanned leathers for low amounts of adsorption are probably related to the carboxyl groups in the tannin. Part of the water that combines with these materials is undoubtedly associated with these groups.

Collagen contains both carboxyl and amino groups. The amino group is known to be less active in the formation of hydrogen bonds than the carboxyl group. It is also probable that a certain amount of interaction exists between these two groups in the native protein and therefore their reaction with water would not be highly energetic. This explains why collagen has the lowest heat of adsorption for water of the three materials. A further explanation for the higher heat of adsorption for the leathers follows from the preceding hypothesis. If the tanning material combined with the amino group of collagen, it would tend to release strongly ionized protein carboxyl groups and consequently to increase heat of adsorption. This reaction is similar to that which takes place when amino acids are neutralized by alkali in the presence of formaldehyde [17].

For $V / V_{m}$ values greater than one, the three materials show similar behavior with respect to the change in heat of adsorption with increasing water adsorption. It would, of course, be expected that the heat of adsorption would decrease as the number of layers increase. The results might, however, be equally well explained by assuming that the part shown on the graph for less than one monolayer take-up was for adsorption on the strong surface groups as described above. Beginning at a $V / V_{m}$ value of one where the three materials reach a common point, it may be assumed that the more active groups take up additional water by dipole-dipole attraction with decreasing energy. At a $V / V_{m}$ value of about 2.5 the curves tend to flatten out and to become parallel with the line representing the heat of condensation for water. The distance from the heat of condensation line to that for chrome leather and collagen, respectively, might be related to the heat of swelling for these materials. However, it is most probable that the lines are approaching the heat of condensation asymptotically, as would be expected for the adsorption of an infinite number of layers of water.

\section{Graphical Presentation of Water Adsorption Data}

The plot given in figure 8 shows the relation between the log of the moisture adsorbed and the inverse of the absolute temperature. It is possible to estimate from this relation the amounts of moisture adsorbed at equilibrium at temperatures and relative humidities not studied experimentally. A similar relation was shown to exist for textile materials by Wiegerink [9].

Another valuable method for the representation of moisture relation data has been applied by Whitwell and Toner [6] to textile materials. They adapted this method from a basic relation first used by Othmer [11] for representing the vapor pressure of pure liquids. The Clausius-Clapeyron 


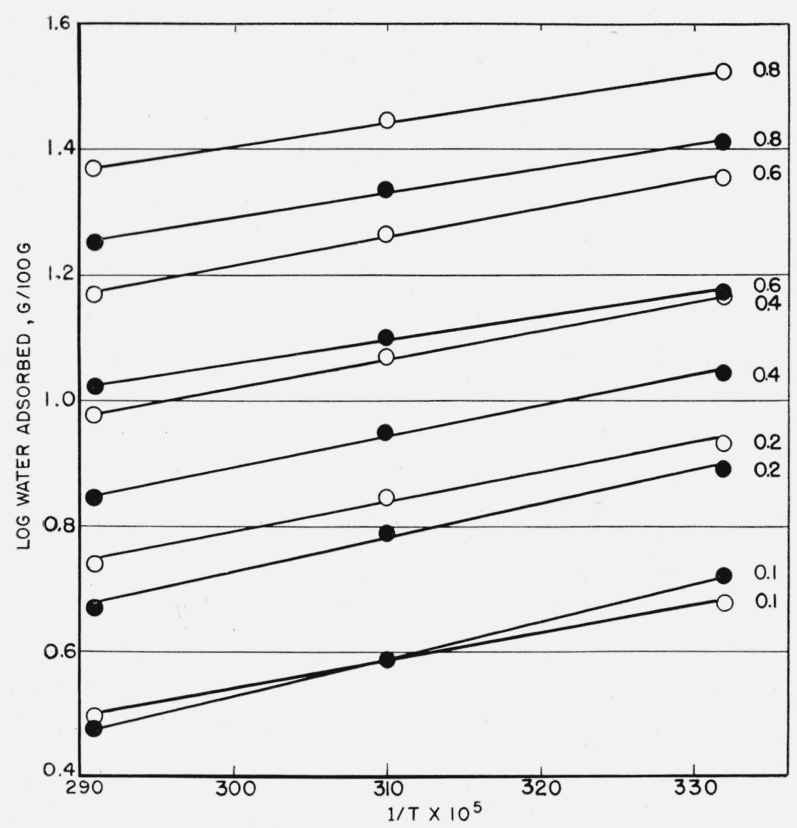

Figure 8. Variation of the log of the percentage of moisture adsorbed for sole leather, $\mathbf{O}$, and collagen, $\bigcirc$, with the reciprocal of the absolute temperature.

equation representing the equilibrium between pure water and its vapor may be written as follows:

$$
\frac{d P_{0}}{P_{0}}=\frac{\Delta H_{0} d t}{R T^{2}},
$$

where $P_{0}$ is the vapor pressure of water, and $\Delta H_{0}$ is the heat of condensation. For water vapor over the adsorptive material in question, the equation may be written as follows:

$$
\frac{d P}{P}=\frac{\Delta H d t}{R T^{2}}
$$

where $P$ is the vapor pressure of water over the material, and $\Delta H$ is the heat of adsorption. These two equations may be combined to give the following relation:

$$
\log P=\frac{\Delta H}{\Delta H_{0}} \log P_{0}+C .
$$

A plot of $\log P$ against $\log P_{0}$ should yield a straight line if $\Delta H$ is proportional to $\Delta H_{0}$ in the temperature range of interest. Lines representing constant regains (constant moisture contents) over a range of temperatures and relative humidities are obtained in this way. The temperature dependence is expressed in terms of $\log P_{0}$.
In figure 9 the water adsorption relations of collagen are plotted according to this method, and in figure 10 a similar plot is shown for vegetabletanned belting leather. The graphs indicate that the water adsorption data for both of these materials are accurately represented by eq 7 .

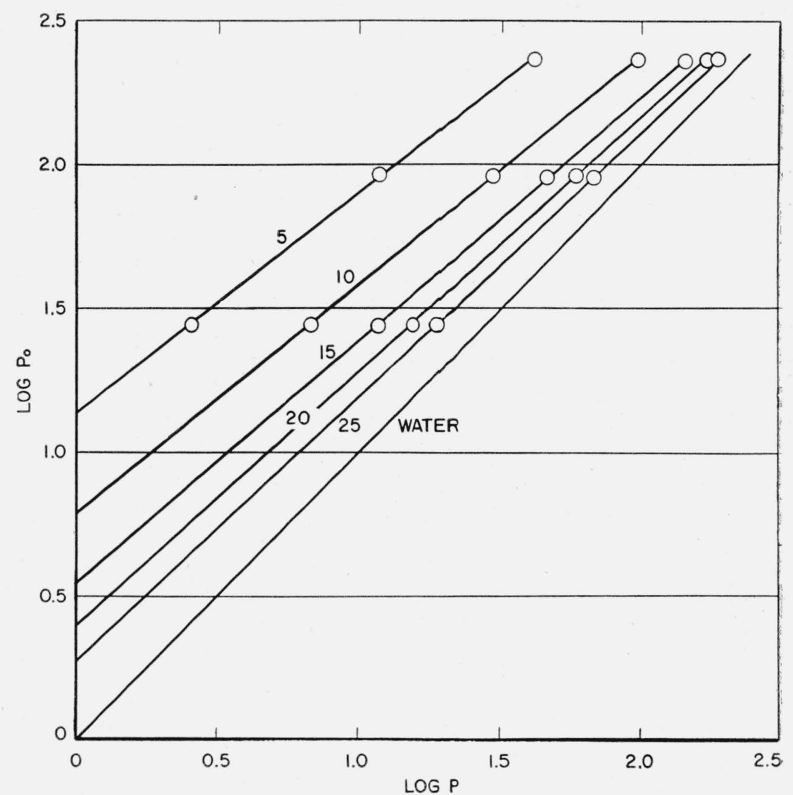

Figure 9. Equilibrium moisture contents of collagen plotted as a function of $\log P_{o}$ and $\log P$.

Numbers on curves indicate moisture contents in percentage.

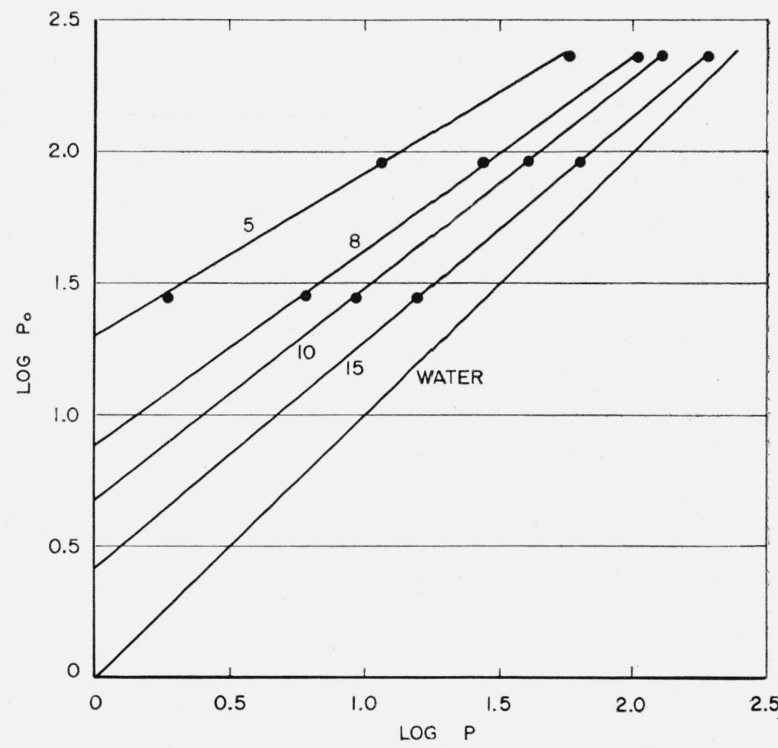

Figure 10. Equilibrium moisture content of vegetabletanned belting leather plotted as a function of $\log P_{o}$ and $\log P$.

Numbers on curves indicate moisture contents in percent. 
Lines representing constant moisture contents are obtained. The water reference line is obtained by plotting the vapor pressure of water as a function of $P$ against $P_{0}$. As the amount of water adsorbed increases, the lines approach more closely the water reference line. It may be noted that the slopes of the lines change with increasing amounts of adsorption. This indicates changes in the heats of adsorption. These lines may be extrapolated as shown, and adsorption values obtained for other conditions for which no data were obtained.

The lines, when extended in the direction of increasing $\log P$, approach intersection at a "common point." The position of this point is assumed by Whitwell [6] to be related to the swelling characteristics of the material. It may readily be seen that the lines given for leather will meet in a common point at a lower value of $\log P$ than those for collagen. This can be demonstrated by observing the ratios of the distances between two corresponding lines at $P$ values of $\log 0.5$ and $\log 1.5$. According to this hypothesis, collagen, as expected, shows the greater amount of swelling.

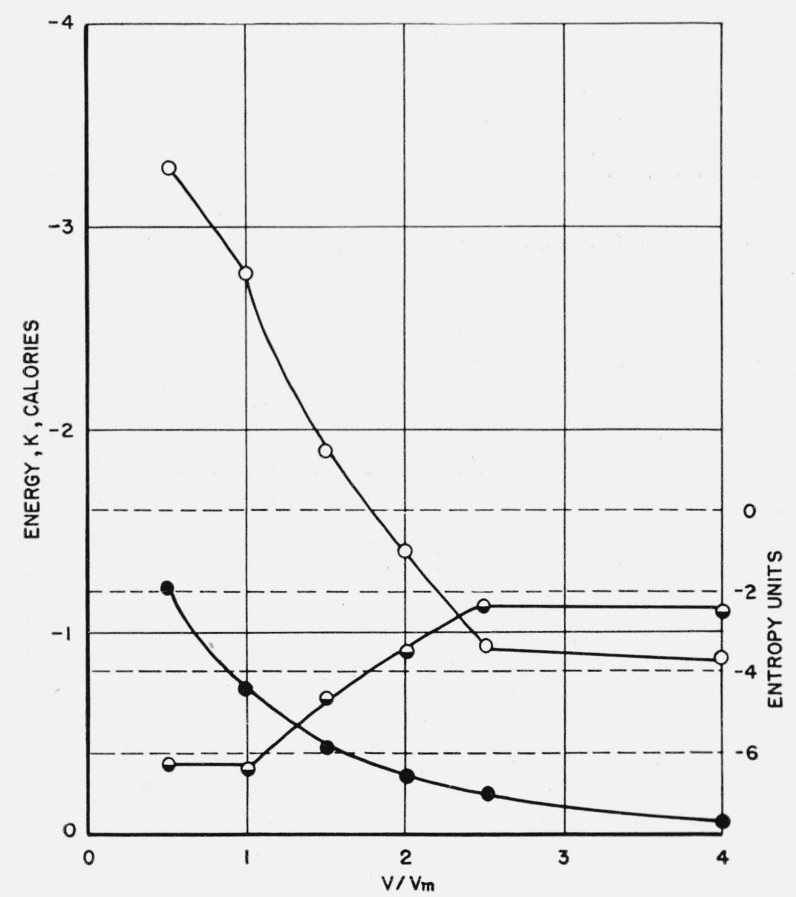

Figure 11. Change of free energy $\overline{\Delta F_{1}}$, - and heat of adsorption $\overline{\Delta H_{1}}, \bigcirc$, with $V / V_{m}$ for collagen at $50^{\circ} \mathrm{C}$.

\section{Calculation of Free Energy and Entropy}

From the free energy values for the system and the differential heats of adsorption calculated by the Clausius-Clapyron equation, it is possible to calculate the entropy change for the process

$$
\begin{gathered}
\mathrm{H}_{2} \mathrm{O} \text { (liquid) } \rightleftarrows \mathrm{H}_{2} \mathrm{O} \text { (adsorbed), } \\
\overline{\Delta F}_{1} \text { for the system }=R T 1 \mathrm{n}=\frac{P}{P_{0}} .
\end{gathered}
$$

$\overline{\Delta H}_{1}$ is the difference between the differential heat of adsorption and the heat of liquefaction. The entropy change $\overline{\Delta S}_{1}$ is then calculated from the equation

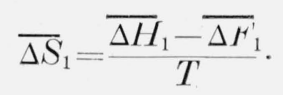

Values of $\overline{\Delta F}_{1}, \overline{\Delta H}_{1}$, and $\overline{\Delta S}_{1}$ for collagen, hide powder, and four samples of leather at $50^{\circ} \mathrm{C}$ are given in table 6 . In figure 11 , the results of $\overline{\Delta F}_{1}, \overline{\Delta H}_{1}$, and $\overline{\Delta S}_{1}$ for collagen are plotted against $V / V_{m}$. The $\overline{\Delta H}_{1}$ values show a rapid drop near the ordinate where $V / V_{m}$ is equal to 1. At the same point the entropy $\left(\overline{\Delta S}_{1}\right)$, which is always negative, becomes smaller.

The results given in table 6 show much larger $\overline{\Delta S}_{1}$ values for 5-percent water adsorption for the leathers than for collagen and hide substance. Between 5 and 10 percent adsorption, $\overline{S \Delta}_{1}$, for all the samples except collagen decreases.

The values of $\overline{\Delta S}_{1}$ and $\overline{\Delta H}_{1}$ for the adsorption of water by collagen, given in table 5 , are of the same order of magnitude as those given by Frey and Moore [5] for glycine, leucine, and diketopiperazine. The energy with which an unhydrolyzed protein binds water appears, therefore, to be similar in magnitude to that of its individual components.

\section{Effect of Preheating on Adsorptive Properties}

Since the results of the studies on the adsorption of water vapor at $50^{\circ}$ and $70^{\circ} \mathrm{C}$ indicated decreasing BET surface areas with increasing temperature, experiments were made to obtain more information on the effect of exposure at elevated temperatures on adsorption. Samples of chromeleather, chrome-retanned leather, vegetabletanned belting leather, and collagen were heated in 
TABLE 6.-Heat af adsorption $\left(\overline{\Delta H}_{1}\right)$, free energy $\left(\overline{\Delta F}_{1}\right)$, and entropy $\left(\overline{\Delta S}_{1}\right)$ values at $50^{\circ} \mathrm{C}$

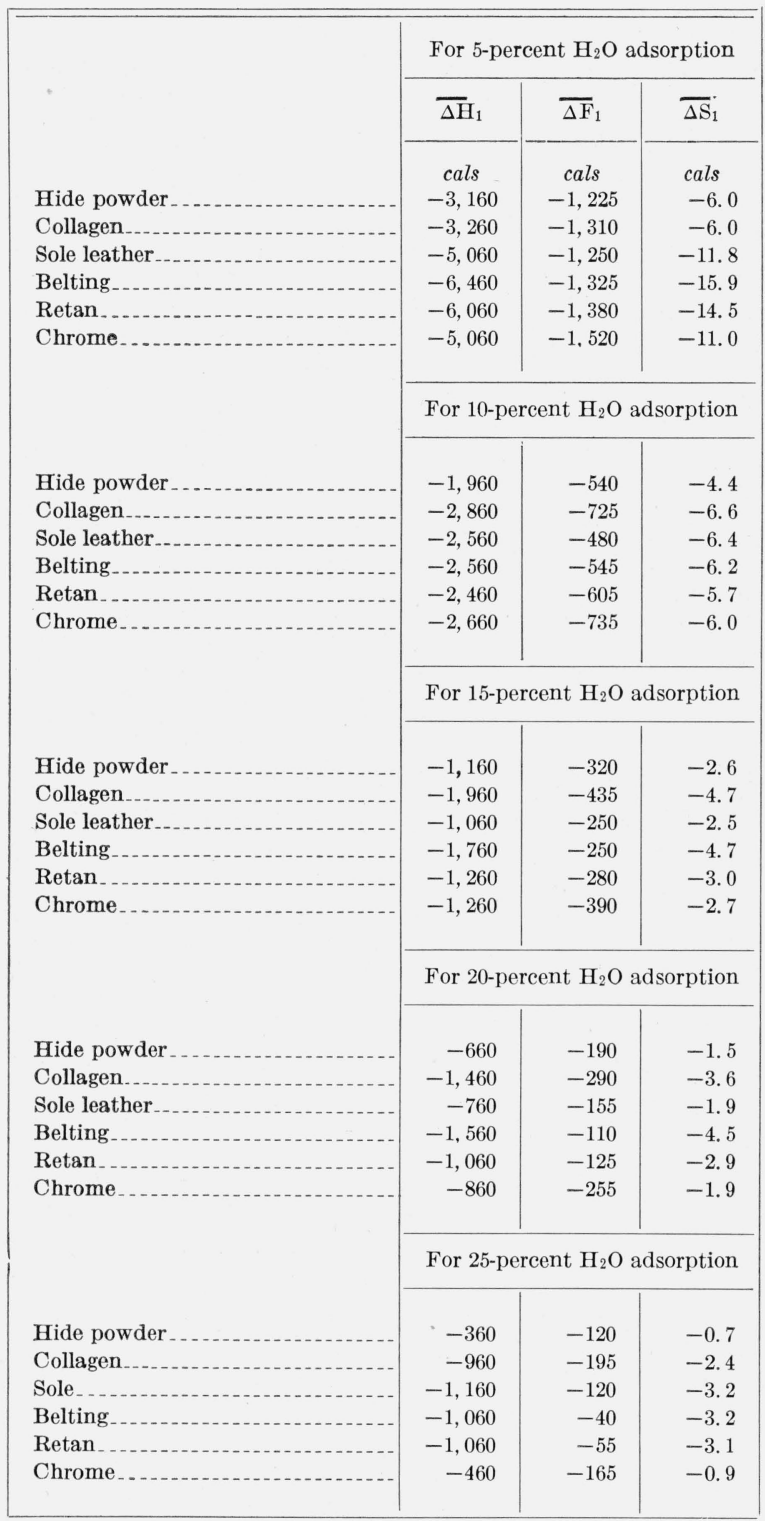

air at $100^{\circ}, 120^{\circ}$, and $140^{\circ} \mathrm{C}$ for $24 \mathrm{hr}$. Since it was supposed that the collagen might be affected by a temperature lower than that required to affect the leathers, a sample of collagen was heated also at $80^{\circ} \mathrm{C}$ for $24 \mathrm{hr}$. Adsorption measurements were made on the heated samples at $28^{\circ} \mathrm{C}$ by the method described in section III.

The results of the adsorption measurements are given in table 7, and typical sets of isotherms for the heated specimens of collagen are given in figure 12. It may be noted that heating at $80^{\circ} \mathrm{C}$ had practically no effect on the adsorption. This indicates that little deterioration occurs below this temperature Results for vegetable-tanned leather are given in figure 13. These results show considerable decrease in adsorption, the decrease depending on the temperature of preheating.

In figure 14 the water adsorbed by the heated samples at 14-percent relative humidity and $28^{\circ} \mathrm{C}$ is plotted against the temperature of preheating.

The results indicate that the adsorptive capacity of the leathers for moisture decreases more rapidly

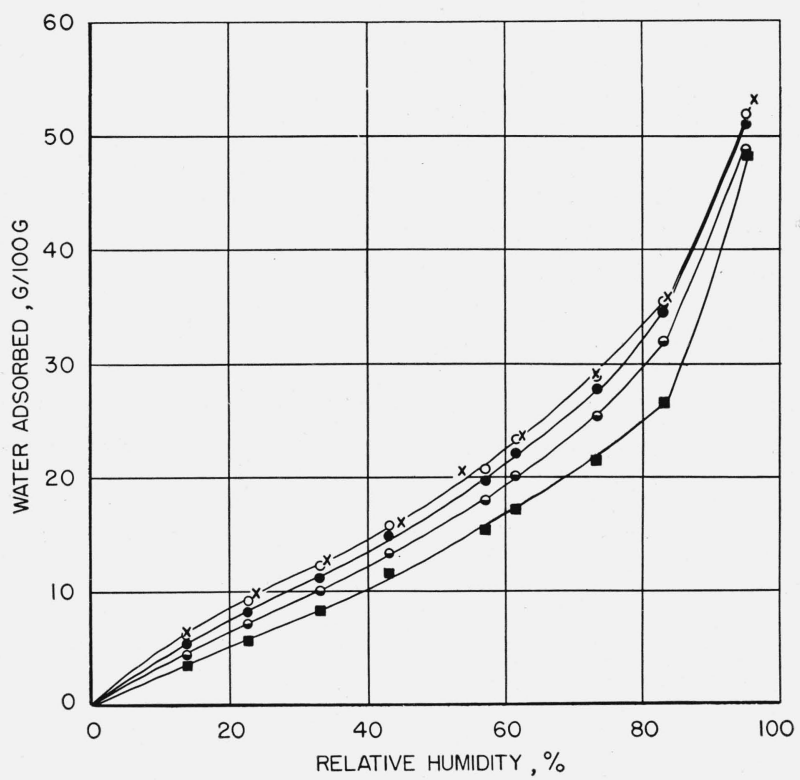

Figure 12. Effect of preheating on moisture adsorption by collagen.

Temperature of heating: Not heated, $\mathrm{X}: 80^{\circ} \mathrm{C}, \bigcirc ; 100^{\circ} \mathrm{C},-120^{\circ} \mathrm{C}$, $140^{\circ} \mathrm{C}$,

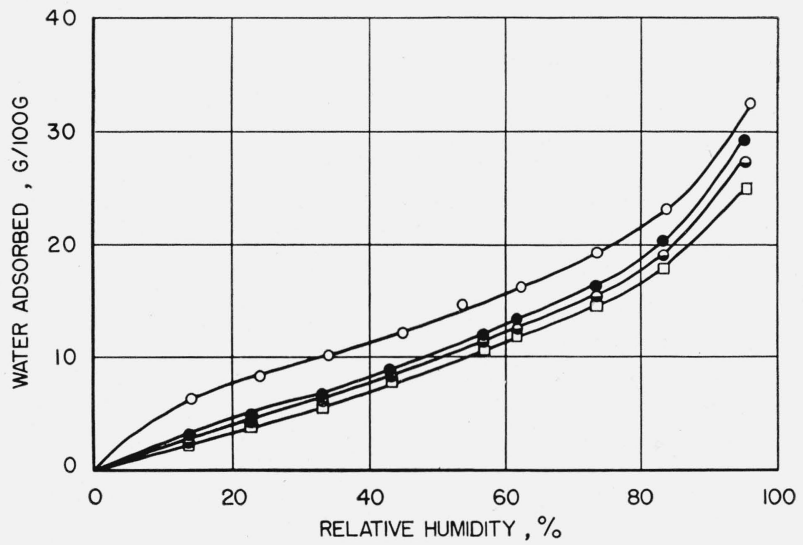

FIGURE 13. Effect on preheating on moisture adsorption by vegetable-tanned belting leather.

Temperature of heating: Not heated, $\bigcirc ; 100^{\circ} \mathrm{C}, \bullet, 120 \mathrm{C}, \boldsymbol{\top} ; 140^{\circ} \mathrm{C}, \square$. 
TABLE 7. Water adsorbed at $28^{\circ} \mathrm{C}$ by collagen and various leathers after heating at different temperatures

\begin{tabular}{|c|c|c|c|c|c|c|c|c|c|c|}
\hline \multirow{2}{*}{ Material } & \multirow{2}{*}{$\begin{array}{c}\text { Tem- } \\
\text { pera- } \\
\text { ture } \\
\text { of } \\
\text { heating }\end{array}$} & \multicolumn{9}{|c|}{ Relative humidity } \\
\hline & & 13.8 & 22.6 & 33.1 & 43.1 & 56.6 & 61.6 & 73.5 & 83.2 & 95.0 \\
\hline \multirow{5}{*}{ Collagen... } & ${ }^{\circ} \mathrm{C}$ & $g / 100 \mathrm{~g}$ & $g / 100 g$ & $g / 100 g$ & $g / 100 g$ & $g / 100 g$ & $g / 100 g$ & $g / 100 g$ & $g / 100 g$ & $g / 100 g$ \\
\hline & 100 & 5.39 & 8. 23 & 11. 24 & 14.85 & 19. 69 & 22.24 & 27.77 & 34.43 & 50.96 \\
\hline & 120 & 4.52 & 7. 19 & 10.08 & 13.45 & 17. 96 & 20.28 & 25.48 & 31.88 & 48.81 \\
\hline & 140 & 3.59 & 5.81 & 8.39 & 11.62 & 15.55 & 17.32 & 21.58 & 26. 69 & 48.41 \\
\hline & 100 & 3.81 & 5. 70 & 7.57 & 10.01 & 13.22 & 14.69 & 17. 96 & 22.16 & 31.40 \\
\hline \multirow{3}{*}{ Chrome-retanned upper leather...... } & 120 & 1.97 & 3. 80 & 5. 61 & 8.02 & 11. 16 & 12.65 & 15. 78 & 19.82 & 28.82 \\
\hline & 140 & 1.74 & 3. 38 & 5.06 & 7.40 & 10.49 & 11.95 & 14.82 & 18.46 & 26.65 \\
\hline & 100 & 3.06 & 4. 92 & 6.76 & 9.04 & 11.94 & 13.34 & 16.54 & 20.35 & 29.36 \\
\hline \multirow{3}{*}{ Vegetable-tanned belting leather...... } & 120 & 2.83 & 4. 60 & 6.39 & 8.64 & 11.46 & 12. 76 & 15.67 & 19.15 & 27.54 \\
\hline & 140 & 2.51 & 4. 06 & 5.66 & 7.84 & 10.74 & 12.06 & 14. 76 & 17.84 & 24. 92 \\
\hline & 100 & 4. 88 & 7. 37 & 10.00 & 13.11 & 17.11 & 19.10 & 24.33 & 31.42 & 54.09 \\
\hline \multirow[t]{2}{*}{ 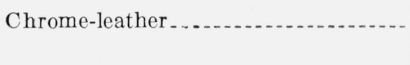 } & 120 & 3. 86 & 6. 36 & 9.01 & 12.18 & 16. 29 & 18. 31 & 23.56 & 30.56 & 53.00 \\
\hline & 140 & 2. 57 & 5. 27 & 7.85 & 10.98 & 14.88 & 16.78 & 21.69 & 28.28 & 51.11 \\
\hline
\end{tabular}

than does that of collagen. It has been shown in previous work [14] that leathers decompose to give off carbon dioxide and water more readily than does collagen. It may be that active groups in leather are removed in this way, thus accounting for the fact that the leather adsorbs less moisture after heating. It was shown in section IV that the tanning of leather did not appear to change its affinity for water vapor at low relative humidities.

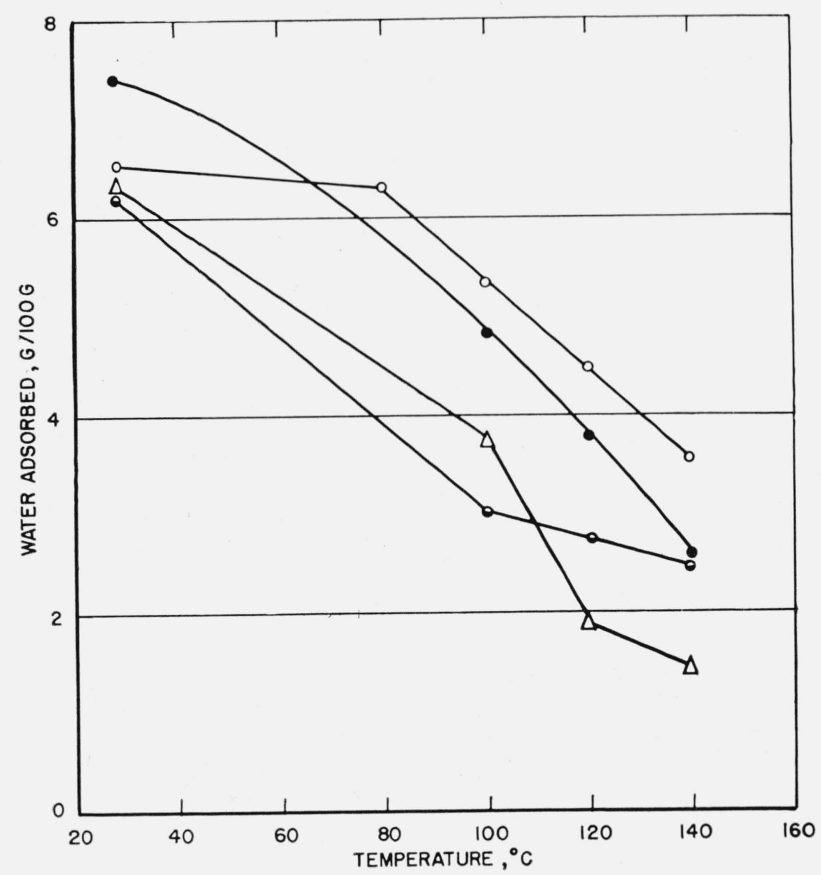

FIGURE 14. Adsorption of water by the preheated samples at 14-percent relative humidity and $28^{\circ} \mathrm{C}$.

Collagen, $\bigcirc$; vegetable-tanned belting leather, $\bullet$; chrome leather, $\bullet$; and chrome-retanned leather, $\triangle$.
It is possible, however, that during heating, tanning materials may combine with certain groups in the collagen of the leather, thus resulting in the loss of the activity of these groups for water. These two possibilities are suggested to explain the differences in behavior between leather and collagen. The changes occurring in the collagen, as shown by water adsorption, are most pronounced between temperatures of $120^{\circ}$ to $140^{\circ} \mathrm{C}$.

In figure 15 the calculated surface areas of the four samples after preheating are shown. It is interesting to note that the chrome-tanned leather

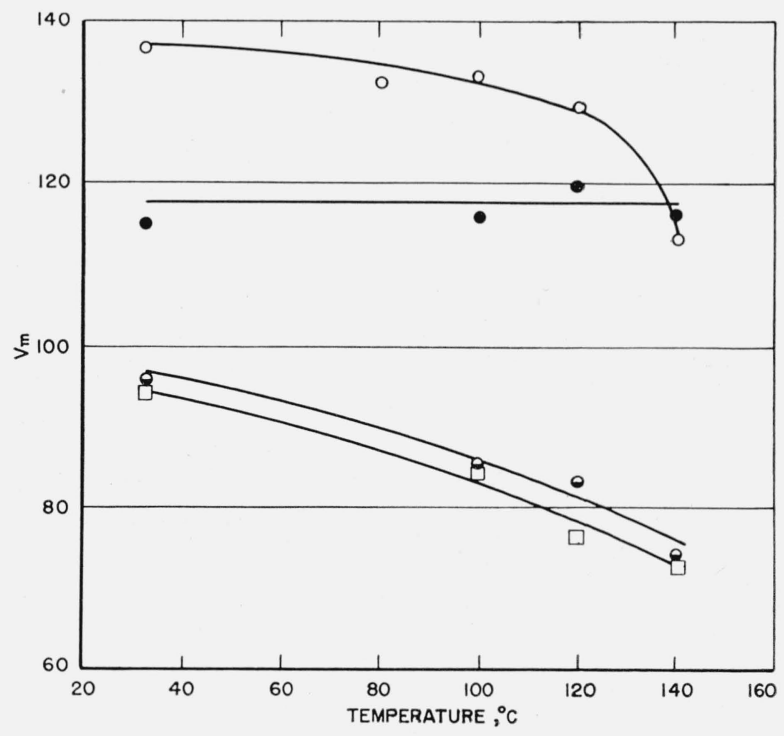

FIGURE 15. Change of the surface areas with temperature of preheating

Collagen, $\bigcirc$; chrome leather, $\mathbf{\theta}$; vegetable-tanned belting leather, $\odot$; and chrome-retanned leather, $\square$. 


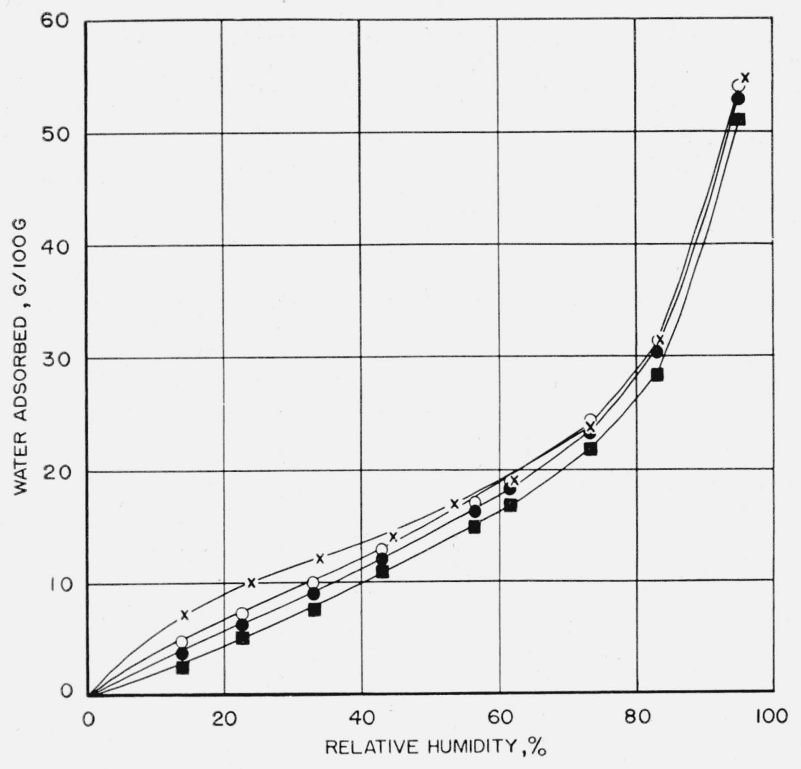

FIGURE 16. Effect of preheating on moisture adsorption by by chrome-tanned leather.

Temperature of heating: Not heated, X; $100^{\circ} \mathrm{C} . \bigcirc ; 120^{\circ} \mathrm{C}, 0 ; 140^{\circ} \mathrm{C}$,

shows no decrease in surface area even when heated at $140^{\circ} \mathrm{C}$, whereas all others show a decrease in surface area. This is an indication of the greater stability of chrome-tanned leather over that of other leathers. This greater stability is also demonstrated by the higher shrinkage temperature of the former in water. The adsorption isotherms for heated chrome-tanned leather are shown in figure 16. It may be observed that in the relative humidity range 60 to 80 percent, the curves for all the heated samples approach fairly closely to the unheated one. By comparing this observation with that for the same range for collagen in figure 12 and that for vegetable-tanned leather in figure 13 , it is obvious that chrome-tanned leather behaves in a different way from these two samples.

Adsorption at relative humidities up to 20 percent occurs on the more active surface groups. The results with chrome-tanned leather indicate that these groups have been altered. However, at the higher relative humidities, adsorption is believed to take place by multilayer formation between the polypeptide chains at the carbonyl groups. The behavior of collagen in this region indicates collapse of the polypeptide chains or the fibrils resulting in a decrease in the number of layers of water that may be adsorbed. Chrometanned leather maintains a high activity toward water in this region, which shows that there is no collapsing of the chains. This is an indication that the chromic oxide combines in such a way as to stabilize the polypeptide chains and thus maintains the high activity of this type of leather toward water vapor.

The heats of adsorption calculated from the BET equations for the heated samples are given in table 8. For all specimens the heats of adsorption are much lower after being subjected to heating. These heats of adsorption are in contrast with those obtained for the samples in the adsorption measurements at $50^{\circ}$ and $70^{\circ} \mathrm{C}$, where the values remained high and nearly constant. This seems to indicate that the decrease in adsorption of the preheated samples was caused by a decrease in the attraction of the active groups for water as well as (except for chrome-tanned leather) a decrease in the number of the active groups. This may be due to the preferential destruction of the more active sites.

TABLE 8. Heat of adsorption at $28^{\circ} \mathrm{C}$ for leathers heated at various temperatures

\begin{tabular}{|c|c|c|c|c|c|c|c|c|c|c|c|c|}
\hline \multirow{2}{*}{ Temperature of preheating } & \multicolumn{3}{|c|}{ Collagen } & \multicolumn{3}{|c|}{ Retan } & \multicolumn{3}{|c|}{ Belting } & \multicolumn{3}{|c|}{ Chrome } \\
\hline & $C$ & $E_{1}$ & $E_{1}-E_{L}$ & $C$ & $E_{1}$ & $E_{1}-E_{L}$ & $C$ & $E_{1}$ & $E_{1}-E_{L}$ & C & $E_{1}$ & $E_{1}-E_{L}$ \\
\hline Not preheated.. & 16.3 & 11,600 & 1,100 & 15.7 & 12,100 & 1,600 & 14.3 & 12,100 & 1,600 & 13.9 & 12,000 & 1,600 \\
\hline $80^{\circ} \mathrm{C}$ & 6.8 & 11,600 & 1,100 & & & & $\ldots$ & & & $\ldots$ & & \\
\hline $100^{\circ} \mathrm{C}$ & 4.8 & 11,400 & 900 & 6.1 & 11,600 & 1,100 & 4. 0 & 11,300 & 800 & 5.2 & 11,500 & 1,000 \\
\hline $120^{\circ} \mathrm{C}_{-}$ & 3.8 & 11,300 & 800 & 3.1 & 11,100 & 700 & 3.7 & 11,200 & 800 & 3.3 & 11,200 & 700 \\
\hline $140^{\circ} \mathrm{C}$ & 3.2 & 11,200 & 700 & 2.8 & 11,100 & 600 & 3.5 & 11,200 & 800 & 2.6 & 11,000 & 600 \\
\hline
\end{tabular}




\section{References}

[1] Joseph R. Kanagy, J. Research NBS 38, 119 (1947); J. Am. Leather Chem. Assoc. 42, 98 (1947).

[2] Linus Pauling, J. Am. Chem. Soc. 67, 555 (1945).

[3] Henry B. Bull, J. Am. Chem. Soc. 66, 1499 (1944).

[4] Malcolm Dole and A. D. McLaren, J. Am. Chem. Soc. 69, 651 (1947).

[5] Harold J. Frey and Walter J. Moore, J. Am. Chem. Soc. \%0, 3644 (1948).

[6] John C. Whitwell and Richard K. Toner, Textile Research J. 16, 255 (1946); 17, 99 (1947).

[7] P. J. MeCarthy, R. K. Toner, and J. C. Whitwell, Textile Research J. 16, 307 (1946).

[8] Richard K. Toner, Carol F. Bowen, and John C. Whitwell, Textile Research J. 17, 7 (1947).

[9] James G. Wiegerink, J. Research NBS 24, 645 (1940) RP1304. J. Research NBS 42, 557 (1949) RP1992.
[10] J. M. Cassel and J. R. Kanagy, J. Research NBS 42, 557 (1949) RP1992; J. Am. Leather Chem. Assoc. 44, 424 (1949).

[11] D. F. Othmer, Ind. \& Eng. Chem. 32, 841 (1940).

[12] L. G. Joyner and P. H. Emmett, J. Am. Chem. Soc. 70, 2353 (1948). J. Research NBS 43, 29 (1949) RP2001.

[13] James M. Cassel and Joseph R. Kanagy, J. Research NBS 43, 29 (1949) RP2001; J. Am. Leather Assoc. 44, 442 (1949).

[14] Joseph R. Kanagy, J. Am. Leather Chem. Assoc. 36, 609 (1941).

[15] Joseph R. Kanagy and Arbelia M. Charles, J. Am. Leather Chem. Assoc. 43, 274 (1948).

[16] Stephen Brunauer, P. H. Emmet, and Edward Teller, J. Am. Chem. Soc. 60, 309 (1938).

[17] G. H. Northrop, J. Gen. Physiol. 16, 41 (1932).

Washington, May 27, 1949. 